\title{
Patents, technological inputs and spillovers among regions
}

\author{
Mercedes Gumbau-Albert ${ }^{\mathrm{a}}$ \\ Joaquín Maudos ${ }^{\text {a,b }}$
}

\begin{abstract}
This paper analyses the importance of different technological inputs (R\&D and human capital) and different spillovers in explaining the differences in patenting among Spanish regions in the period 1986-2003. The analysis is based on the estimation of a knowledge production function. A region's own R\&D activities and human capital are observed to have a positive significant effect on innovation output, measured by the number of patents. $R \& D$ spillovers weighted by the distance and the volume of trade flows between regions cause positive effects on a region's patents. However, distance matters more than the intensity of trade flows and the R\&D spillover effects between regions are bounded: spillovers from closer regions perform better than spillovers from distant regions. On the opposite side, human capital spillovers do not cause any effect outside the region itself.
\end{abstract}

Key words: patents, R\&D, human capital, spillovers.

JEL: O18, O31, R11.

${ }^{a}$ Universitat de Valéncia, Departamento de Análisis Económico; Edificio departamental oriental; Avda. de los Naranjos, s/n; 46022 -Valencia- (Spain) Tel: 34.96.382.82.46; Email: mercedes.gumbau@uv.es (corresponding author).

${ }^{\mathrm{b}}$ Instituto Valenciano de Investigaciones Económicas (Ivie). C/ Guardia Civil 22, Esc. 1, $1^{\mathrm{a}}$. 46020 -Valencia- (Spain). Tel. 34.96.319.00.50. Email: joaquin.maudos@ivie.es. 


\section{Introduction}

In economic literature it is easy to find affirmations that technological innovation is not a random process but requires an economic effort on the part of the agents who undertake it: R\&D expenditure. To be able to bear the risks of this process of investment in $R \& D$, investors patent their innovations. By definition, therefore, patents are related to the process of R\&D. Several authors have examined the structure of the patent-R\&D relationship. Some of them have also taken into account an additional determinant of patents, technological spillovers, but there is almost no research into the relationship between patents and human capital as well as their spillovers. The purpose of this paper is to further explore the link between patents and R\&D activities, as well as that between patents and human capital, by taking into account these spillover effects.

There are important reasons for extending this analysis. First, because a great deal of new economic knowledge relevant to different innovation processes is hard to codify and is therefore not fully available. Any new knowledge of this kind will consist of a vast amount of skills, intuitions and best practices whose transmission will require face to face contacts and extensive explanations. In this case it can be useful to analyse how innovative activities interact with access to human capital in the system of innovation. Second, because the process of innovation is becoming not only more globalised but also more territoriallyspecific. Innovation relies on global knowledge flows, but as these flows become progressively easier to access and exchange thanks to Information and Communication Tecnologies (ITC) and transport links, for example, the territorial aspect of innovation and learning has become a key resource in competitive advantage. In this case it can be useful to analyse whether the transmission of technological information generated by other agents changes with distance. New knowledge is often extremely complicated and contains complex, and sometimes tacit, elements which imply that it is often only accessible via interactions within inter-firm innovations networks or general innovation systems that tend to be bounded by geographical proximity. In this case, closeness between agents in the innovation system is likely to offer greater opportunities for face to face interaction which will develop the potential of the innovation system.

This study aims to apply these theories to the case of the regions of Spain, which can be considered differentiated regions insofar as each is a territorial unit characterised by a productive specialisation and an endowment of factors that distinguish it from the rest. It seems safe to affirm that if the rate of technical progress differs among nations, industries and firms, it also differs among regions due to variations in productive structures and the 
diversity of firms in them. In this sense, it can be maintained that the geographical region or territory is a strategic factor in development. The reason may be that the geographical concept is associated with regional differences in market relationships, forms of regulation, etc., originating divergences in the organisation of production and in the capacity to innovate. The empirical studies carried out at regional level, like Gumbau and Maudos (2006), support the idea that technological change is a factor associated with the economic development of a region. Several authors have also highlighted the importance of regions in the global economy system (see, for example, Johansson, Karlsson and Stough, 2001 and 2002). According to their view, global trade takes the form of interaction between urban regions rather than between countries, i.e. the dynamics operate more at the local level.

According to these new ideas, the main contributions of this paper to the literature are, first, to quantify the impact of human capital on patenting, considering that this aspect has not been well documented in the literature, and second, to quantify the effect of different types of spillovers on patenting. More precisely, the paper examines the correlation between patents and innovation inputs by measuring spillovers at different geographical distances but also by measuring spillovers embedded in trade between regions. Previously, Autant-Bernard (2001) and Acs et al. (2002) compared different geographical levels by introducing external research stock occurring in neighbouring areas. Bottazzi and Peri (2003) use distance in kilometres between different regions to investigate the importance of geographical proximity in knowledge spillovers. Alongside this, an influential literature argues that trade promotes knowledge flows between trading partners (see a survey in Lumenga-Neso et al., 2005). The seminal paper is the study by Coe and Helpman (1995) who specify R\&D spillovers as an import-share weighted sum of R\&D expenditures in their countries. Their results support the view that $R \& D$ spillovers are traded-related. This paper combines and compares these two approaches: on the one hand, neighbouring areas and distance in kilometres and, on the other hand, spillovers transferred with trade. Furthermore, the concept is applied not only in terms of R\&D but also in terms of human capital. This paper could also help local decision makers to deal with questions like: Should they invest to increase local R\&D? Should they invest to increase local higher education? Should they invest to increase both local R\&D and local higher education to take advantage of highly educated labour?

The present paper tests, for the case of the Spanish regions, the hypothesis that the patent activity within each region can be related to technological inputs to that territory as well as to spillovers or technological activities carried on outside the region. These technological inputs are measured by R\&D expenditure and research human capital. The results show that a region's own $R \& D$ activities and human capital have a positive significant 
effect on innovation output, measured by the number of patents. However, the spillover effects between regions are bounded: R\&D expenditures cause positive effects on a region's patents depending on the distance and the volume of trade flows between the two regions, while human capital spillovers do not cause any effect outside their own region.

The paper is organized as follows. The second section presents the related literature on patents, $R \& D$, research human capital and spillovers. The third section sets out the context in which we analyze the effects of technological inputs on regional patenting. In the fourth section we present the statistical sources and variables used in the empirical analysis in order to explore the technological reality of the Spanish regions. The fifth section shows the results of the estimation of the knowledge production function. And, finally, the sixth section offers the conclusions and policy implications of the study.

\section{Related literature}

It is widely known that the economic growth of countries or regions can differ according to their rates of technological innovation. This allows new productive knowledge to be obtained which, once applied, generates new goods and services or produces the existing ones more efficiently. The question is how countries or regions access this technology. The most important way is by generating their own technology through their own R\&D activities and human capital. However, scientific and technical advances cannot always be used by the entity that makes the expenditure, and they therefore generate spillovers. In this sense, the R\&D activities generated by other nearby agents, and the purchase of innovations through trade in goods and services, are also ways of accessing technology.

The technological innovation of each region is formed by the R\&D expenditures and human capital in that region, and the spillovers associated with technological capital or human capital produced outside the region but "absorbed" by it. The basic relationship between patents and R\&D has been analysed empirically by authors such as Griliches (1984), Hall, Griliches and Hausman (1986), Meliciani (2000), Blundell, Griffith and Windmeijer (2002) and Bottazzi and Peri (2003) and, theoretically, the models of Romer (1990) and Jones (1995) assume that new ideas are generated using R\&D resources as well as existing ideas as inputs. As distant knowledge is not always completely appropriated by its producers, the research effort of other regions can allow a given region to obtain more patents with less research effort. Hence, R\&D spillovers exist if the patenting in a region is affected by the amount of $R \& D$ resources used in other regions in "spatial proximity" or "technological 
proximity".

The question is to identify where these spillovers come from. Among the first authors to introduce the concept of spillover of technological capital were Scherer (1982), Spence (1984), Jaffe (1986) and Jaffe et al. (1993) at the level of the firm, while the existence of spillovers at international level is reflected in the studies by Berstein and Mohen (1998) and Coe and Helpman (1995). These studies define alternative measurements for spillovers such as R\&D expenditure by other firms or industries, weighted where appropriate for "technological proximity" or "spatial proximity".

According to Jaffe (1986), spillovers are generated in "technological proximity". For this reason, technological areas in which firms are engaged in research are identified, i.e. spillovers depend on the nature of the firms' research. Results show that spillovers can be positive or negative. However, Jaffe et al. (1993) analyze the effect of spillovers on patents under the assumption that knowledge spillovers are geographically localized ("spatial proximity"). Using patent citations they find that spillovers are more likely to come from the local areas than from abroad.

According to Glaeser et al. (1992) the transmission of technological knowledge occurs within a limited geographical unit. More recently, Audretsch and Feldman (1996), Cincera (1997) and Bottazzi and Peri (2003) have found important sources of localized spillovers. The first of these papers suggests that location and proximity impact directly on innovativeness. More specifically, these authors distinguish between the transmission of information and the transmission of knowledge, indicating that, though the cost of transmitting information may not vary with distance, the cost of transmitting knowledge does increase with distance, since the transmission of knowledge requires continuous contacts and interaction between agents .

The second paper analyses the relationship between patents and lagged levels of R\&D expenditures and technological spillovers. Technological and geographical opportunities are also taken into account as additional determinants. In order to examine this relationship, several econometric models for count panel data are estimated. The main findings of the paper are first, a high sensitivity of results to the specification of patent distribution, and second, a positive impact of technological spillovers on firms' own innovation.

The third paper exploits the spatial correlation between patents and R\&D activity by measuring spillovers at different geographical distances. The authors find that spillovers are 
highly localized and exist only within a distance of $300 \mathrm{~km}$, even when simultaneity problems, omitted variable bias, different specifications of distance functions, and country and border effects are considered. That is to say, location and the closeness of the productive agents to each other are important, as although the cost of transmitting information may be invariable with distance, the cost of transmitting new technological knowledge, which is not generally done explicitly, does vary with distance.

In the same direction, Fritsch and Franke (2004) investigate the impact of knowledge spillovers and R\&D cooperation on innovation activities, and they demonstrate that interregional differences can be explained by $R \& D$ spillovers from other $R \& D$ activities by actors located in the same region, while $R \& D$ cooperation plays a minor role as a medium for knowledge spillovers.

Strong evidence is provided for both the US and Europe that knowledge flows measured by patent citations are bounded within a relatively narrow geographical range (Jaffe, Trajtenberg and Henderson, 1993; Almeida and Kogut, 1999). Empirical analysis also shows that the production of new scientific and technological knowledge has a predominant tendency to cluster spatially. Sensitivity of the transmission of new knowledge to distance seems to provide a principal reason for the development of regional innovation clusters (Acs, Anselin and Varga, 2002).

While still using patents as a measure of innovative activity in one region, Piergiovanni and Santarelli (2001) test for France the hypothesis that patent activity within each administrative region is related to $R \& D$ expenditure on that territory as well as research expenditure undertaken in universities or public research centres in the same area. The findings of this paper show that spillovers from university research are, relatively, a more important source of patenting than industrial research itself.

Related to this paper, though they estimate the external effect of R\&D on productivity rather than on patents, is the paper by Eaton and Kortum (1999) which analyzes the invention of new technologies and their diffusion across countries. In their model, research effort is determined by how much ideas earn at home and abroad. When they fit the model to data from the five leading research economies, they find that research performed abroad is about two-thirds as potent as domestic research. So that together the United States and Japan drive at least two-thirds of the growth in each of the other countries in the sample. Also, Chuang and Hsu (2004) find that foreign ownership and trading with more advanced countries helps to gain access to new technology and information, which improves productivity and helps to 
compete in international markets. In the same direction Huilin and Song (2005) show empirically that $R \& D$ is positively relates with foreign investment and Chen and Yang (2005) explore the relationship between knowledge, spillovers and productivity finding a very significant contribution of $R \& D$, patents and spillovers stock to productivity.

In this context our paper analyses the effect of spillovers on patents in a region. We would like to observe if those knowledge spillovers are more likely to occur within close geographic proximity to the source of knowledge. Therefore it will be necessary to apply a weighting system to partners' $\mathrm{R} \& \mathrm{D}$, as not all regions in Spain will have the same technological impact on, or from, each other due to geographical distance.

Besides, we are going to build R\&D spillovers embodied in trade because, in parallel to the literature that emphasizes the importance of $R \& D$ spillovers based on proximity, an influential literature argues that trade promotes knowledge flows between trading partners. The basic idea is that $\mathrm{R} \& \mathrm{D}$ expenditure creates new intermediate goods which are different from or better than those already existing and if these are exported to other economies, then the importing economies are implicitly utilizing the technology from abroad. An economy should benefit more from foreign R\&D the higher the country's overall import share. For this reason, the seminal paper of Coe and Helpman (1995) constructed what the authors call the "foreign stock of knowledge" (R\&S spillovers) as a weighted sum of the R\&D expenditures of the country's trading partners, where the weights are given by the bilateral shares ${ }^{1}$. According to Coe and Helpman (1995), their analysis underlines the importance of the interaction between trade and foreign $R \& D$. Their results support the view that $R \& D$ spillovers are trade-related.

Bayouni et al. (1999) also analysed how countries can boost their productivity by trading with countries with large stocks of knowledge. As in Coe and Helpman (1995), the authors consider trade patterns to be the principal transmission mechanism of knowledge among countries. Their results suggest that $R \& D, R \& D$ spillovers and trade play important roles in boosting growth in industrial and developing countries.

Also empirically, Keller (2002) analyses the relationship between productivity and $\mathrm{R} \& \mathrm{D}$ in different industries and finds that technology in the form of product designs is

1 Coe, Helpman and Hoffmaister (1997) use import shares of intermediate goods as weights, while in Coe and Helpman (1995), R\&D spillovers are constructed as a weighted average of the domestic R\&D of trading partners using bilateral import shares as weights. 
transmitted to other industries, both domestically as well as internationally, through trade in differentiated intermediate goods. This process of generation or application of technological knowledge cannot take place without qualified labour or human capital, as a significant part of technology is formed by the body of knowledge acquired by people with access to higher levels of education or to training programs established by firms. In this sense, then, the technical progress or technological innovation of each territory is made explicit not only in its expenditure on $R \& D$ but also in its human capital and its capacity to absorb the spillovers generated by other territories 2 .

Also concentrating on trade-related spillovers, Verspagen (1997), at the macro level, estimates international technological spillovers using technology flow matrices. And at regional level, Gumbau and Maudos (2006) quantify the effect of the regions's own technological innovation, and the externalities associated with technological capital, on regional development. Results show that the technological spillovers between the Spanish regions are always highly significant. Finally, Lumenga-Nelso et al. (2005) argue that "indirect" trade-related R\&D spillovers also take place between countries. Their results suggest that these indirect trade-related spillovers are as least as important as the direct ones, and strengthen the view that trade does matter for the international transmission of R\&D.

Transfers of knowledge and spillovers embodied in human capital will also be analysed. The theoretical basis of the relationship between human capital and innovation at the country level was established by Bourdieu (1986) and validated by Gradstein and Justman (2000) who affirm that those who are better educated, have more extensive work experience, and invest more time and resources in increasing their skills, are better able to contribute to the overall well-being and competitiveness of society. Further, innovation, as well as knowledge intensity, is expected to be related to human capital in several ways. Black and Lynch (1996) proposed that investment in human capital through job training and education is the driving force behind increases in productivity and competitiveness. And Cannon (2000) also argued that human capital raises overall productivity in society as the human input to economic activity in terms of physical and intellectual effort increases. The overall growth in economic activity generates, then, greater need for new processes and innovations to further support this growth. And also Feldman (2000) points out that while the empirical literature has failed to provide evidence of these relationships, one can assume that

2 See, for example, Engelbrech (2002). Using human capital stock variables, he confirms the existence of a positive role for human capital in the absorption of international Knowledge spillovers other than embodied R\&D spillovers. 
highly educated people tend to produce more innovations that nurture the development of industries and lead to regional income and population growth.

The concept of absorptive capacity has so far been associated in the endogenous growth literature with the concept of human capital (Lucas 1988, Romer 1990). In the same line, Engelbrecht (1997) extends the study by Coe and Helpman (1995) by including a human capital variable to account for innovation outside the R\&D sector and other aspects of human capital not captured by formal R\&D. Much of the extant work at both the macro-level and micro-level considers that the primary determinant behind technological accumulation and absorptive capacity is human capital. Indeed, the definition of human capital shares some commonality with the concept of absorptive capacity, and several empirical studies have in fact used human capital measures as proxies for absorptive capacity (see, for example, Verspagen, 1991; and Borenzstein et al., 1998). Both human capital and absorptive capacity involve learning activities and therefore are cumulative processes. Qualified human resources are essential in monitoring the evolution of external knowledge and in evaluating their relevance, and for the integration of these technologies into productive activities.

Much knowledge is embedded in human beings and this indicates that knowledge flows are a function of the mobility and interaction of people with relevant knowledge, skills and experience. Due to the "tyranny of distance" most of the human interaction is bounded to the functional region and in particular to the locality where people live and work.

If knowledge flows are related to the mobility and interaction of people, the high concentration of people and firms in large urban regions can create an environment in which knowledge moves quickly from person to person and from firm to firm. This implies that large dense locations encourage knowledge flows and knowledge exchange, thus facilitating the spread of new knowledge that underlies the creation of new goods and new ways of producing existing goods (Carlino, 2001). Besides, according to according to Ciccone and Hall (1996) and Bottazzi and Peri (2003), density of population determines the historical advantages of being in urban nuclei with a large potential market because people's demand is higher, or maybe large industrial areas with a stock of past accumulated innovations. This variable can also reflect characteristics of the regional environment such as greater endowment of infrastructures, the existence of a regional policy to encourage innovation, etc.

\section{The patent equation}


According to Griliches (1984), patents and R\&D can be related in a "knowledge production function" in which $\mathrm{R} \& \mathrm{D}$ expenditures are the relevant innovative input and the technological knowledge resulting in patented innovations is the innovative output. Although authors like Pavitt (1985), Basberg (1987) and Griliches (1990) have pointed out several problems in using patents as innovative output, this equation has been used in the main studies relating R\&D and patents. Among these problems are, first, that some important technologies are not patented, such as software, which is protected by copyright. Second, not all inventions are patented because firms can protect the returns on their investment in other ways such as through secrecy, lead-time advantages, and marketing. Third, firms patent for different reasons, for example, to protect an invention from imitation, to block competitors from patenting or pursuing a line of research, or to evaluate the productivity of their R\&D activities. And, fourth, patents have widely varying commercial value and therefore significance with respect to innovation. Despite all these arguments, the number of patents is a valid measure of the innovation output of a country or region, because it captures the level of technological activity and because several fundamental conditions need to be fulfilled for an activity or invention to qualify for patent eligibility (see more arguments for using patents as indicators of innovation in Rondé and Husller, 2005). Also Acs et al. (2002) show in a comparison between patents and the literature-based output measure that patents provide a fairly good measure of innovative activity in a knowledge production context.

However, knowledge is not always appropriated completely by its producers; consequently, direct access to inputs producing knowledge is not the only way to get patents. In this sense, Cohen and Levinthal (1989) define absorptive capacity as "the fraction of knowledge in the public domain that the firm is able to assimilate and exploit". It represents the link between the firm's in-house capabilities in developing and improving new products on the one hand, and the external stock of technological opportunities on the other. Absorptive capacity, therefore, although determined in part by the territory's R\&D efforts, also reflects the ability of a territory to integrate its existing and exploitable resources (technological opportunities) into the production chain, and its foresight in anticipating potential and relevant technological trajectories available in other economic actors. The knowledge production function has to be taken in a wide context, including the overall innovation environment. That is, patent activity within a territory is related not only to $R \& D$ expenditure and human capital originated in that region, but also to $R \& D$ expenditures of adjacent regions and territories connected by trade, and embodied knowledge originated by the human capital of the area or nearby areas.

With these arguments, the resulting model of the knowledge production function is: 
That is:

$$
\text { Patents }=F(R \& D, K H, R \& D \text { spillovers, } K H \text { spillovers })
$$

Assuming that the technology underlying the knowledge production function is of the Cobb-Douglas type, the knowledge production function for the Spanish regions, augmented with spillovers, is:

$\ln P A T_{i t}=\beta_{1} \ln \left(R \& D_{i t}\right)+\beta_{2} \ln \left(K H_{i t}\right)+\beta_{3} \ln \left(R \& D \quad\right.$ spillovers $\left._{i t}\right)+\beta_{4} \ln \left(K H\right.$ spillovers $\left._{i t}\right)+\varepsilon_{i t}$

where:

$P A T_{i t}=$ patent applications of region $i$ in year $t$

$R \& D_{i t}=$ a measure of the innovation expenditure made by region $i$ in year $t$

$K H_{i t}=$ a measure of human capital of region $i$ in year $t$

$R \& D$ spillovers $_{i t}=$ spillovers of $\mathrm{R} \& \mathrm{D}$ absorbed by region $i$ in year $t$

KH spillover $_{i t}=$ spillovers of innovation embodied in human capital absorbed by region $i$ in year $t$.

The technological innovation of each region is formed by the R\&D expenditures and human capital in that region, and the spillovers associated with technological capital and human capital produced outside the region but "absorbed" by each region. To test the hypothesis that patenting is increased by the technology embodied in R\&D and human capital of the "relevant" neighbours, we first follow Jaffe et al. (1993) in assuming that knowledge spillovers are geographically localized and, second, we follow Grossman and Helpman (1994) and Coe and Helpman (1995), who support the idea that the new theory of economic growth underlines trade as a transmission mechanism linking a country's productivity gains to economic development in its trade partner. More precisely, not only does a region's productivity depend on its own technological research, it also depends on the technology of its trade partners, i.e. the more open an economy is to trade, the stronger the effect of foreign or neighbouring R\&D on domestic productivity. 


\section{Statistical sources and variables used}

In order to analyse the contribution of $R \& D$ activities and human capital to regional patenting, we present below the variables that are to be used in the empirical analysis. These correspond to the seventeen Autonomous Communities (regions) of Spain in the period 19862003. R\&D expenditures are expressed in pesetas of 1995 and have been deflated by the deflator of the Gross Formation of Fixed Capital provided by the Instituto Nacional de Estadística (INE).

The variables and statistical sources used are:

a) Patent applications (PAT), measured by the number of patents applied for by each of the regions. They are obtained from the statistics of the Registro de la Propiedad Industrial (Oficina Española de Patentes y Marcas. Ministerio de Industria y Energía).

b) Human capital $(K H)$, i.e. the level of qualified labour of each region, has been proxied by the percentage of the workers with university education, this being the proxy used in several papers (Barro and Lee, 1994; Lichtenberg, 1994; among others) ${ }^{3}$. This information is obtained from the Fundación Bancaja publication "Series of human capital: 1964-2004" by Mas, Pérez, Serrano, Uriel, and Soler (2005). Alternatively, and with the aim of checking the robustness of the results, we will also use as a proxy variable for human capital the percentage of the workers with secondary and higher education.

c) Regionalised $\mathrm{R} \& \mathrm{D}$ expenditure $(R \& D)$ obtained from the INE's publication "Statistics on activities in Scientific Research and Technological Development", except those for 1986 which were obtained from the estimations by Martin et al. (1991). The publication offers information both on total $\mathrm{R} \& \mathrm{D}$ expenditure and on disaggregated figures for the following sectors: Firms, Public Administrations, Higher Education and Private Non-profit Bodies (PNPB). The latest regionalised information available is for 2003.

d) Density of population (Population). The allocation of R\&D or human capital

3 As proxy variables for human capital, Rondé and Husller (2005) use the percentage of population devoted to R\&D, and Bottazzi and Peri (2003) use the share of college graduates in the population. 
across regions may be affected by some regional characteristics. In this paper the variable used to proxy these characteristics is density of population (inhabitants $/ \mathrm{Km}^{2}$ ). Information comes from the Instituto Nacional de Estadística (INE).

e) Spillovers associated with technological activities and human capital. In order to analyse the contribution of spillovers of a technological nature to patents at the regional level, several complementary measurements have been constructed which take into consideration the possibility that the spillovers captured by each region may come from other regions.

Specifically, the spillover effects of each region are constructed as a weighted sum of the technological inputs of the rest of the regions:

$$
S P I L L=W_{N x N} R_{N x 1}
$$

where $W_{N x N}$ is the matrix of weightings of the technological inputs $(R)$ of the rest of the regions.

In this study, the matrix used is based on the volume of trade flows between regions and on geographical proximity. Specifically, we use two alternative matrices of weightings which result in several alternative measurements of spillover effects. The weightings of the matrix are constructed as follows:

$$
\begin{gathered}
f_{i j}{ }^{1}=\frac{F_{i j}}{\sum_{j=1}^{N} F_{i j}} \\
f_{i j}{ }^{2}=\frac{K M_{i j}}{\sum_{j=1}^{N} K M_{i j}}
\end{gathered}
$$

where $F_{i j}$ measures the flow of trade between regions $i$ and $j$, and $K M$ is the distance in kilometres between regions $i$ and $j$.

On the basis of the two weightings matrices, several measurements of spillover effects are calculated, both for R\&D expenditures and for human capital:

1) (R\&D-TOTAL) and (KH-TOTAL) measure spillovers captured by each region 
from all the other regions, i.e. taking into account the addition of all the R\&D expenditures (R\&D-TOTAL) or human capital (KH-TOTAL) of all the Spanish regions except that region itself.

2) $(R \& D-N)$ and $(K H-N)$ measure spillovers captured by each region from neighbouring regions, i.e. taking into account the addition of all the R\&D expenditures $(R \& D-N)$ or human capital $(K H-N)$ of the closest regions, those sharing a border with the region in question.

3) $(R \& D-K M)$ and $(K H-K M)$ measure spillovers taking into account the geographical proximity (distance in Kilometres) between regions, such that the nearer the other region, the greater the weighting given to its $\mathrm{R} \& \mathrm{D}$ expenditures $(R \& D-K M)$ or its stock of human capital $(K H-K M)$.

4) (R\&D-TF) measures spillovers taking into account the intensity of the trade flows between regions, such that the greater the value of the trade flows with another region, the greater the weighting given to its R\&D expenditures. In other words, interregional $R \& D$ spillovers are specified as a trade-share weighted sum of the R\&D expenditure in other regions. This specification implies that the more a region trades with another region, the more $R \& D$ spillover benefits are received by the importing region. Thus, each element of the weightings matrix measures the importance of the trade flow between regions $i$ and $j$ in relation to the total volume of the region of origin $i$.

In the case of human capital, it has only been weighted by distance and not by trade flows between regions. It seems reasonable to think, as Audretsch and Feldman (1996) state, that the transmission of knowledge requires interaction between agents and continuous contacts and, consequently, is not transmitted with the trade flow.

To calculate the weightings matrix on the basis of the importance of trade flows we use the information supplied by the Instituto Nacional de Estadistica (INE) on trade flows by road (no information is available for other means of transport). Specifically, the variable that it supplies is the freight transported by road (thousands of tonnes) between regions (origindestination matrix). In the case of weightings based on geographical proximity, we use the distance by road in kilometres between the capitals of each region. Since the flows refer to road transport, there is no information for the island regions (Balearics and Canaries), so the sample consists of 15 regions. 


\section{A knowledge production function for the Spanish regions: empirical results}

To show the technological position of the Spanish regions we will start by presenting the main indicators of technological activities. Table 1 shows the total expenditure on $R \& D$ by the Spanish regions, expressed as a percentage of Gross Domestic Product (GDP). In Spain this ratio shows substantial growth in the period 1986-2003: from $0.62 \%$ of GDP in 1986 , over the next seventy years it increased by 0.48 percentage points to $1.10 \%$ in 2003 . However, despite the substantial increase in $R \& D$ expenditure, the ratio is well below the average for the European Union-15 (2.00\% of GDP), only the Madrid region (1.81\%) being near average European levels. The information by regions shows the existence of substantial differences. Using the information for the last year, 2003, only four regions stand above the national average: Madrid, Catalonia, Navarra and the Basque Country. The Balearic Islands, Castilla-LaMancha and Extremadura are well below the average. It can also be observed that, in the last period, the ratio has increased in all the regions with the exception of Asturias, Cantabria and Castilla-La Mancha.

$>$ Insert table $1<$

Table 2 contains the regional distribution of total expenditure on R\&D. The information shows that in 1986 three regions (Madrid, Catalonia and the Basque Country) concentrated almost $75 \%$ of total R\&D expenditure, while some regions did not even reach $1 \%$ of the total (the case of the Balearics, the Canaries, Cantabria, Castilla-LaMancha, Extremadura, La Rioja and Murcia). However, in 2003 Madrid, Catalonia and the Basque Country concentrated a lower percentage of R\&D expenditure (less than 60\%) while the regions that started from less favourable positions had improved.

\section{$>$ Insert table $2<$}

Table 3 shows the regional distribution of the number of patents applied for in the different Spanish regions between 1986 and 2003 (see also figure 1 showing a map of the Spanish regions with the distribution of patents in 1986 and 2003). As can be observed, the number of patents applied for in 2003 was 2,804 (last row), and the number had increased during the 1990s more slowly than during the 1980s. The percentage distribution shows that Catalonia and Madrid concentrate nearly $45 \%$ of the total of patents applied for in 2003, as against $62.5 \%$ in 1986 , having thus lost relative weight in the course of time. They are 
followed in importance, at a distance, by the Valencia Region (nearly 14\%), Andalusia $(9.5 \%)$, and the Basque Country (nearly $6 \%$ ).

$>$ Insert table $3<$

$>$ Insert figure $1<$

Table 4 shows the results of the knowledge production function introduced by equation 3. In order to treat appropriately the specific issues arising from the discreteness of patent counts, econometric models for count panel data have to be implemented, because the discrete non-negative nature of the dependent variable generates non-linearities that make the usual linear regression models inappropriate. The usual way to deal with the discrete nonnegative nature of the dependent variable is to consider a Poisson regression model. The patents $\left(P A T_{i t}\right)$ are assumed to be independent and have Poisson distributions with parameters $\lambda_{\text {it }}$ (the Poisson arrival rate of innovation) that depend on a set of explanatory variables $\left(X_{i t}\right)$ which are in this case the determinants of the knowledge production function. The patents $\left(P A T_{i t}\right)$ are related to this function through the conditional mean of the Poisson model. The advantage of this specification is that when $X_{i t}$ variables are expressed in logarithms, $\beta_{i}$ parameters are elasticities and are estimated by the maximum likelihood method.

However the Poisson model has an important drawback: when overdispersion arises for reasons such as unobserved heterogeneity, the binomial negative model is often better adapted (Greene, 2000). Thanks to the introduction of a new parameter "Delta" this generalisation of the Poisson model accounts for the heterogeneity of the dependent variable. The estimation and significance of this parameter indicate whether this model is to be preferred to the traditional specification of the Poisson model ${ }^{4}$. As Delta is statistically different from zero, we use a negative binomial regression to estimate the knowledge production function. Additionally, as a panel data is available (cross-regional and time series dimension), and with the aim of controlling for individual unobserved heterogeneity between regions, we estimate a fixed effects negative binomial model with time effects.

The elasticity of $R \& D$ expenditure can be interpreted as an indicator of the productivity of the input to the innovation output, and hence of the efficiency of the innovation system in a certain region. The results of table 4 show an elasticity of R\&D that

4 The variance of the negative binomial model is equal to the variance of the Poisson model multiplied by the coefficient of over-dispersion, Delta. The limit case where Delta equals zero corresponds to the Poisson model. Hence, to test the appropriateness of the negative binomial regression, we provide the Delta statistics in the tables of results. 
varies between 0.17 and 0.27 , being statistically significant (at $1 \%$ level). Consequently the results show, as expected, the importance of technological inputs in explaining the evolution of regional patenting. Authors like Griliches (1984), Bottazzi and Peri (2003) and Fritsch and Franke (2004) also obtain results that emphasize the importance of R\&D efforts for obtaining patented results. However, although R\&D resources in one region contribute to an increase of its own patenting activity, the percentage is lower than that found in the above mentioned papers.

$>$ Insert table $4<$

The results obtained after estimating the spillover effects associated with $R \& D$ expenditures report that a statistically significant effect is obtained in three out of the four measurements of spillover effects used. Concretely, we find that R\&D invested in adjacent regions $(R \& D-N)$ and not the total of Spain's $\mathrm{R} \& \mathrm{D}(R \& D-T O T A L)$ has a positive effect on a region's patents, i.e. the geographical proximity between regions matters. This result is confirmed when we use $\mathrm{R} \& \mathrm{D}$ weighted by kilometres $(R \& D-K M)$ as a proxy for the spillovers. In addition, $R \& D$ weighted by trade $(R \& D-T F)$ has the same positive effect. However, the effect of external $\mathrm{R} \& \mathrm{D}$ weighted by trade on innovation $(R \& D-T F)$ is only a small fraction of the effect of external R\&D weighted by kilometres $(R \& D-K M)$ or the effect of spillovers coming from neighbouring regions $(R \& D-N)$.

The greater elasticity of $R \& D-N$ (2.65) compared to $R \& D-K M(2.45)$ confirms the existing empirical evidence that shows that $R \& D$ spillovers tend to be limited to areas in close vicinity to the source (see for example Acs et al., 1992; Audretsch and Feldman, 1996; Jaffe et al., 1993; and Anselin et al., 1997). In the same direction, empirical analyses such as Baptista and Swann (1999) and Porter (1998) identify a tendency for innovative activity in the same technological area to be clustered in space. The results also confirm the evidence found by Keller (2002) at the regional level, and Bottazzi and Peri (2003) who do not find local spillovers past the distance of $300 \mathrm{~km}$. Thus, it is possible to conclude that spillovers are spatially localized. The part of knowledge that generates externalities relies on formal close contacts and remains more localized.

In table 4 , according to equation 3 , we also estimate the elasticity of innovation measured by patents to a region's own human capital and to human capital belonging to other regions at different distances. We use as a proxy for human capital the percentage of workers 
with university education $(K H)$, and all the results show that own human capital plays a great part in generating patents. As in Bottazzi and Peri (2003), the effect of human capital on innovative output is large and significant ${ }^{5}$.An elasticity higher than 1 in most of the cases indicates that innovative output increases in proportion to rising human capital input. This result means that workers with higher schooling levels should be more effective in generating innovation. However we do not find any evidence of human capital externalities, i.e. spillovers of human capital are geographically bounded. The same effect is obtained whatever spillovers are constructed including the total human capital (KH-TOTAL), the human capital of neighboring areas $(K H-N)$ and the human capital weighted by the proximity between regions $(K H-K M)$. In this direction, Bottazzi and Peri (2003) maintain that while codified knowledge is accessible everywhere, non-codified knowledge attached to people is less accessible and harder to disseminate as it relies more on face to face contacts. The physical distance between a researcher and the place where an idea is discovered can make the knowledge associated with this idea less accessible for the researcher.

The density of population variable (Population) is not statistically significant. It is well known that firms in more densely populated regions are better able to exploit their longer existing knowledge stock and industrial infrastructures because of their accessibility. More specifically, density of population is synonymous with accessibility and better accessibility may increase the probability of firms and individuals coming into touch with different people and new ideas. Also accessibility affects innovation through riskminimization, as the possibility for the innovative firm to reach a higher number of potential buyers increases the chances for innovative products. This result has also been pointed out by Bottazzi and Peri (2003) and Fritsch and Franke (2004). Also Varga (1998a, 1998b and 2000) studied the effect of agglomeration on regional academic technology transfers from US metropolitan areas and these studies demonstrate diverse regional impacts of the same amount of research depending on the level of economic activities in the geographical area. However we do not find any significant effect. The main reason that can justify the absence of significance of density of population is the fact that this variable has little temporal variability for each region. Also, and as a consequence of the previous point, the potential influence of the density of population (which is used as a proxy variable for some regional characteristics such as endowment of infrastructures, the existence of a regional policy to

5 Rondé and Hussler (2005) test the influence of the regional stock of knowledge on regional innovative dynamism (patents) using different indicators of human capital (percentage of the population devoted to research). Bottazzi and Peri (2003) also analyze the importance of human capital (proxied by the share of college graduate in the population of a region). Their results show that the effect of human capital on innovative output is significant. 
encourage innovation, etc) will already be captured by the fixed effects (which capture the effects of unobserved region-specific factors).

Finally, we have checked the robustness of the results in three directions ${ }^{6}$. First, results are robust to alternative proxies for human capital (the percentage of population with secondary and higher education). Second, we have studied the possibility of a lag structure between R\&D expenditure and patents. More precisely, we have analysed the robustness of the results introducing multiple lags (specifically, the first, second and third lag) of the R\&D expenditure and the spillovers of R\&D. However, the lagged variables are not statistically significant. And third, taking into account that the existence of universities could help to explain the differences observed in innovative activity among the Spanish regions, we have re-run the estimations including as explanatory variable the number of universities established in each region ${ }^{7}$. Its effect, although positive, is not statistically significant.

\section{Summary, conclusions and policy implications}

The objective of this paper is to analyse the effect of technological activities on patenting in the Spanish regions for the period 1986-2003. Using the regional information we estimate, together, the effect of $R \& D$ expenditure and human capital on patents on the basis of the estimation of a knowledge production function expanded with spillovers of technological inputs. These spillovers are proxied, alternatively, by the R\&D expenditures of other regions at different distances or with different trade flows, and also by the human capital of other regions at different distances. The main contributions of this paper to the literature are, first, to quantify the impact of human capital and its spillovers on patenting, considering that this aspect has not been well documented in the literature; and second, to quantify the impact of different types of spillovers on patenting: spillovers based on distance and spillovers based on trade flows among regions. Some papers have analysed the importance of each of them but without comparing the relative effect of both.

The main results of the study are as follows:

a) There is a positive correlation between the patents of the regions and their $R \& D$

\footnotetext{
6 Results are available upon request to the authors.

7 Unfortunately, the available statistical information for the Spanish regions does not allow us to analyze the effect of other regional characteristics on the innovative activity.
} 
expenditures. Thus, the regions that make a greater effort in $R \& D$ are those that reach higher levels of patented innovations. Consequently, it is necessary to invest in inputs of innovation (R\&D) to reach higher levels of output of innovation (patents).

b) We find a positive relationship between the levels of human capital and the number of patents among the Spanish regions, confirming the hypothesis that the higher the level of human capital, the higher will be the region's level of innovation. The elasticity of human capital shows that this is also an important source of generating patents in the Spanish regions. Local innovation is thus positively affected by research carried out by a region's own human capital and by its own R\&D spending.

c) The estimation of a knowledge production function augmented with spillovers of $R \& D$ shows that a region is more affected by its neighbouring regions than by the activity of agents that are physically more distant. That is to say, spillovers are geographically bounded and close regions have more impact on a region's patenting than the set of technological activities generated by the total of the regions.

d) We have also found trade-related interregional R\&D spillovers. However, distance matters more than the intensity of trade flows in transferring spillovers of $R \& D$. Thus, the proximity effect on technological spillovers is greater than the effect of trade flows.

e) There is no evidence of human capital spillovers, possibly because knowledge embodied in people requires face to face contact to spill over. In that case human capital at a distance does not produce a significant effect on regional patenting. The physical distance between a researcher and the place where an idea is discovered can make the knowledge associated with this idea less accessible for the researcher.

The policy implications deriving from the results obtained are that 1) the innovative potential of a region depends not only on its investment in R\&D but also on the existence of investment in human capital. Consequently, innovation policies have to be based on R\&D investment, but must also include policies designed to generate and attract human capital. These policies can complement $\mathrm{R} \& \mathrm{D}$ decisions, producing a habitat more conducive to creativity, innovation, and ultimately, economic growth; and 2) the importance of the R\&D spillovers shows that from a regional policy point of view, a region's innovative capacity depends not only on its own investment in R\&D but also on that of the rest of the regions. Consequently, as well as the technological initiatives of regional governments, there must be a national $R \& D$ policy to enable the advantages of the existence of technological spillover 
effects among regions to be exploited and to reduce regional inequalities in endowments of technological capital.

One of the limitations of our study is that we do not know the mechanisms through which human capital fosters innovation. Thus, future research studies may shed light on this issue using alternative proxy variables for human capital. Additionally, another issue for future research is the study of other regional characteristics that can explain the differences observed in innovative activity (existence of university-business links, industry characteristics, sector specialisation of the region, existence of incubators, etc.).

\section{Acknowledgements}

The authors are grateful for the comments made by an anonymous referee and for the financial assistance of the Instituto Valenciano de Investigaciones Económicas (Ivie). This study was carried out in the framework of research projects SEJ2004-00110 and SEJ200502776 of the Spanish Ministry of Science of Tecnlology-FEDER. 


\section{References}

Acs, Z., Anselin, L., Varga, A. 2002. Patents and innovation counts as measures of regional production of knowledge. Research Policy 31, 1069-1083

Almeida, P., Kogut, B. 1999. The localization of knowledge and the mobility of engineers. Management Science 45, 905-917.

Anselin, L., Varga, A., Acs, Z. 1997. Local geographic spillovers between university research and high technology innovations. Journal of Urban Economics 42, 422-448.

Audretsch, D., Feldman, M. 1996. R\&D spillovers and the geography of innovation and production. American Economic Review 86, 641-652.

Autant-Bernard, C. (2001), Science and knowledge flows: Evidence from the French case, Research Policy 30, 1069-1078

Baptista, R. and Swan, P. 1999. A comparison of clustering dynamics in the US and UK computer industries. Journal of Evolutionary Economics 9, 373-399.

Barro, R.J., Lee, J.W. 1994. Sources economic growth, Carnegie-Rochester Conference Series on Public Policy 40, 1-46.

Basberg, B.L. 1987. Patents and the measurement of technological change: a survey of the literature. Research Policy 16, 131-141.

Bayoumi, T., Coe, D., Helpman, E. (1999). R\&D spillovers and global growth. Journal of International Economics 47, 399-428.

Bernstein, J., Mohnen, P. 1998. International R\&D spillovers between US and Japanese R\&D intensive sectors. Journal of International Economics 44, 315-338.

Black, S., Lynch, L. 1996. Human capital investments and productivity, American Economic Review 86, 263-268.

Blundell, R., Grifith, R., Windmeijer, F. 2002. Individual effects and dynamics in count data models. Journal of Econometrics 108(1), 113-131.

Borenzstein, E., De Gregorio, Lee, J.W. 1998. How does FDI affect economic growth. Journal of International Economics 45, 115-135.

Bottazzi, L., Peri, G. 2003. Innovation and spillovers in regions: evidence from European patent data. European Economic Review 47, 687-710.

Bourdieu, D. 1986. The forms of capital. In Richardson, J. Handbook of theory and research for the sociology of education. New York: Greenwood.

Cannon, E. 2000. Human capital: level versus growth effects. Oxford Economic Papers 52, 
670-677.

Carlino, G.A. 2001. Knowledge spillovers: cities' role in the new economy. Federal Reserve Bank of Philadelphia Business Review Q4, 17-23

Cheng, J. and Yang, C. (2005) "Technological knowledge, spillover and productivity: evidence form Taiwanese firm level panel data", Applied Economics 37, 2361-2371.

Chunag, Y. and Hsu, P. (2004) "FDI, trade and spillover efficiency: evidence from China's manufacturing sector”, Applied Economics 36, 1103-1115.

Ciccone, A., Hall, R. 1996. Productivity and the density of economic activity. American Economic Review 86(1), 54-70.

Cincera, M. 1997. Patents, R\&D, and Technological Spillovers at the Firm Level: Some Evidence from Econometric Count Models for Panel Data. Journal of Applied Econometrics $12,265-80$.

Coe, D., Helpman, E. 1995. International R\&D spillovers. European Economic Review 39, 859-887.

Coe, D., Helpman, E., Hoffmaister, A. 1997. North-South R\&D Spillovers. Economic Journal vol. 107(440), 134-49.

Cohen, W., Levinthal, D. 1989. Innovation and learning: the two faces of R\&D. Economic Journal 99, 369-596.

Eaton, S., Kortum, S. 1999. International Technology Diffusion: theory and measurement. International Economic Review 40, 537-570.

Engelbretch, H. J. 1997. International R\&D spillovers, human capital and productivity in OCDE economies: an empirical investigation. European Economic Review 41(8), 1479-88.

Engelbretch, H. J. 2002. Human capital and international knowledge spillovers in TFP growth of a sample of developing countries: an exploration of alternative approaches. Applied Economics 34, 831-841.

Feldman, M. 2000. Location and innovation: the new economic geography of innovation, spillovers and agglomeration. In The Oxford Handbook of Economic Geography, Oxford University Press.

Fritsch, M., Franke, G. 2004. Innovation, regional knowledge spillovers and R\&D cooperation. Research Policy 33, 245-255.

Glaeser, E, Kallal, H., Scheinkman, J., Schleifer, A. 1992. Growth in cities. Journal of Political Economy 100(6), 1126-1142.

Gradstein, M., Justman, M. 2000. Human capital, social capital and public schooling. European Economic Review 44, 879-891. 
Greene, G. 2000. Econometric Analysis, Prentice Hall International Edition

Griliches, Z. 1984. R\&D, patents and productivity. The University of Chicago Press.

Griliches, Z. 1990. Patent statistics as economic indicators: a survey. Journal of Economic Literature 28, 1661-1707.

Grossman, G., Helpman, E. 1994. Protection for sale. American Economic Review 84, 833850.

Gumbau, M., Maudos, J. (2006). Technological activity and economic growth in the Spanish regions. The Annals of Regional Science 40(1), 55-80.

Hall, B., Griliches, Z., Hausman, J. 1986. Patents and R\&D: is there a lag?. International Economic Review 27, 265-83.

Huilin, L. and Song, Y. (2005) "The interdependence between FDI and R\&D: an application of an endogenous switching model to Taiwan's electronics industry", Applied Economics 37, 1789-1799.

Jaffe, A. 1986. Technological opportunities and spillovers of R\&D: evidence from firms' patents, profits and market value. American Economic Review 76, 984-1001.

Jaffe, A., Trajtenberg, M., Henderson, R. 1993. Geographic localization of knowledge spillovers as evidenced by patent citation. Quarterly Journal of Economics 108(3), 577-598.

Johansson, B., Karlsson, C., Stough, R. (eds.). 2001. Theories of endogenous regional growth. Lessons for regional policies, Berlin; Springer-Verlag

Johansson, B., Karlsson, C., Stough, R. (eds). 2002. Regional policies and comparative advantages, Cheltenham, UK; Edward Elgar.

Jones, C. 1995. R\&D based models of economic growth. Journal of Political Economy 103(4), 759-84.

Keller, W. 2002. Geographic localization of international technology diffusion. American Economic Review 92 (1), 120-142

Lichtenberg, F. 1994. Have international differences in educational attainment levels narrowed?. In W.J. Baumol, R.R. Nelson, E.W. Wolff (eds.) Convergence of productivity: cross-national studies and historical evidence, Oxford University Press, Oxford.

Lucas, R. 1988. On the mechanism of economic development. Journal of Monetary Economics 22, 3-42.

Lumenga-Neso, O., Olarreaga, M., Schiff, M. 2005. On "indirect" trade-related R\&D spillovers. European Economic Review 49, 1785-1798. 
Martín, C., Moreno, L., Rodríguez, L. 1991. Estimación de la distribución regional de las actividades de I+D. Documento de Trabajo No 71/1991. FIES

Mas, M., Pérez, F., Serrano, L., Uriel, E., Soler, A. 2005. Series de capital humano 19642004. Fundación Bancaja, Valencia.

Meliciani, V. 2000. "The relationship between R\&D, investment and patents: a panel data analysis", Applied Economics 32, 1429-1437.

Pavitt, K. 1985. Patent statistics as indicators of innovation activities. Scientometrics 7, 7799.

Piergiovanni, R., Santarelli, E. 2001. Patents and the geographic localization of R\&D spillovers in French manufacturing. Regional Studies 35, 697-702.

Porter, M. 1998. Clusters and the new economics competition. Harvard Business Review Nov.Dec, 77-90.

Romer, P. 1990. Endogenous technical change. Journal of Political Economy 98(5), 71-102.

Rondé, P., Hussler, C. 2005. Innovation in regions: what does really matter?. Research Policy 34, 1150-1172.

Scherer, F.M. 1982. Demand pull and technological innovation: Schmoockler revisited. Journal of Industrial Economics 30, 5-237.

Spence, A.M. 1984. Cost reduction, competition and industry performance. Econometrica 52, 101-121.

Varga, A. 1998a. University research and regional innovation: a spatial econometric analysis of academic technology transfers, Kluwer Academic Publishers, Boston.

Varga, A. 1998b. Local Academic knowledge spillovers and the concentration of economic activity. Research Paper, Regional Research Institute, West Virginia University.

Varga, A. 2000. Universities in local innovation systems. In Acs, Z. (ed.) Regional Innovation, Knowledge and global change, Pinter, New York.

Verspagen, B. 1991. A new empirical approach to catching up or falling behind. Structural Change and Economic Dynamics 2 (2), 359-80

Verspagen, B. 1997. Estimating international technological spillovers using technology flow matrices. Weltwirtschaftliches Archiv 133, 226-248 
Table 1: R\&D expenditure by regions (\% GDP)

\begin{tabular}{|l|rrrrr|}
\hline & $\mathbf{1 9 8 6}$ & $\mathbf{1 9 9 0}$ & $\mathbf{1 9 9 5}$ & $\mathbf{2 0 0 0}$ & $\mathbf{2 0 0 3}$ \\
\hline Andalusia & 0.33 & 0.44 & 0.59 & 0.66 & 0.89 \\
Aragon & 0.35 & 0.53 & 0.61 & 0.71 & 0.74 \\
Asturias & 0.39 & 0.52 & 0.55 & 0.83 & 0.70 \\
Balearics & 0.09 & 0.10 & 0.17 & 0.23 & 0.25 \\
Canaries & 0.11 & 0.26 & 0.43 & 0.49 & 0.54 \\
Cantabria & 0.23 & 0.40 & 0.55 & 0.47 & 0.46 \\
Castilla-La Mancha & 0.10 & 0.14 & 0.43 & 0.56 & 0.44 \\
Castill-Leon & 0.42 & 0.51 & 0.50 & 0.64 & 0.88 \\
Catalonia & 0.53 & 0.84 & 0.90 & 1.11 & 1.37 \\
Extremadura & 0.22 & 0.29 & 0.28 & 0.53 & 0.62 \\
Galicia & 0.21 & 0.30 & 0.48 & 0.64 & 0.85 \\
La Rioja & 0.01 & 0.12 & 0.35 & 0.59 & 0.66 \\
Madrid & 1.66 & 2.21 & 1.64 & 1.66 & 1.81 \\
Murcia & 0.20 & 0.42 & 0.51 & 0.71 & 0.73 \\
Navarra & 0.37 & 0.81 & 0.74 & 0.91 & 1.42 \\
Basque Country & 0.67 & 1.06 & 1.16 & 1.17 & 1.42 \\
Valencia Region & 0.17 & 0.32 & 0.50 & 0.73 & 0.87 \\
Total & & & & & 1.10 \\
\hline
\end{tabular}

Source: INE and FUNCAS 
Table 2: Regional distribution of R\&D expenditure (\%)

\begin{tabular}{|l|rrrrr|}
\hline & $\mathbf{1 9 8 6}$ & $\mathbf{1 9 9 0}$ & $\mathbf{1 9 9 5}$ & $\mathbf{2 0 0 0}$ & $\mathbf{2 0 0 3}$ \\
\hline Andalusia & 7.89 & 7.45 & 9.71 & 9.48 & 11.00 \\
Aragon & 2.10 & 2.19 & 2.46 & 2.35 & 2.06 \\
Asturias & 1.93 & 1.57 & 1.63 & 2.00 & 1.38 \\
Balearics & 0.34 & 0.26 & 0.47 & 0.61 & 0.56 \\
Canaries & 0.75 & 1.13 & 2.02 & 2.09 & 2.05 \\
Cantabria & 0.51 & 0.62 & 0.85 & 0.63 & 0.53 \\
Castilla-La Mancha & 0.63 & 0.61 & 1.88 & 2.07 & 1.35 \\
Castill-Leon & 4.81 & 3.72 & 3.78 & 3.90 & 4.47 \\
Catalonia & 16.89 & 19.04 & 21.04 & 22.07 & 22.84 \\
Extremadura & 0.67 & 0.62 & 0.60 & 0.99 & 0.98 \\
Galicia & 2.17 & 2.05 & 3.33 & 3.66 & 4.12 \\
La Rioja & 0.02 & 0.11 & 0.33 & 0.48 & 0.45 \\
Madrid & 47.74 & 44.31 & 33.98 & 30.63 & 28.57 \\
Murcia & 0.86 & 1.22 & 1.43 & 1.82 & 1.64 \\
Navarra & 1.12 & 1.72 & 1.56 & 1.65 & 2.17 \\
Basque Country & 8.45 & 8.51 & 9.04 & 8.04 & 8.12 \\
Valencia Region & 2.97 & 3.85 & 5.88 & 7.53 & 7.69 \\
& & & & & \\
Total & 100.00 & 100.00 & 100.00 & 100.00 & 100.00 \\
\hline
\end{tabular}

Source: INE 
Table 3: Regional distribution of patents (\%)

\begin{tabular}{|c|c|c|c|c|c|}
\hline & 1986 & 1990 & 1995 & 2000 & 2003 \\
\hline Andalusia & 5.46 & 5.95 & 8.49 & 8.45 & 9.52 \\
\hline Aragon & 3.79 & 2.91 & 2.69 & 3.69 & 5.92 \\
\hline Asturias & 0.90 & 0.86 & 1.39 & 1.03 & 1.46 \\
\hline Balearics & 0.71 & 0.82 & 0.82 & 0.96 & 2.07 \\
\hline Canaries & 0.77 & 0.77 & 1.34 & 1.59 & 1.46 \\
\hline Cantabria & 0.39 & 0.68 & 1.20 & 0.59 & 0.53 \\
\hline Castilla-La Mancha & 1.29 & 1.00 & 1.54 & 1.77 & 2.25 \\
\hline Castill-Leon & 1.67 & 2.09 & 2.50 & 3.51 & 2.82 \\
\hline Catalonia & 35.48 & 37.73 & 25.86 & 25.58 & 25.43 \\
\hline Extremadura & 0.13 & 0.59 & 0.67 & 0.81 & 1.28 \\
\hline Galicia & 0.51 & 1.64 & 2.50 & 3.58 & 3.78 \\
\hline La Rioja & 0.58 & 0.59 & 0.86 & 0.78 & 0.68 \\
\hline Madrid & 26.99 & 21.95 & 24.42 & 21.67 & 18.47 \\
\hline Murcia & 1.29 & 1.14 & 1.49 & 2.73 & 1.96 \\
\hline Navarra & 2.76 & 3.09 & 2.78 & 3.06 & 2.32 \\
\hline Basque Country & 7.13 & 8.05 & 8.45 & 6.39 & 5.99 \\
\hline Valencia Region & 10.15 & 10.14 & 13.00 & 13.36 & 13.94 \\
\hline Total (\%) & 100.00 & 100.00 & 100.00 & 100.00 & 100.00 \\
\hline Total number of patents & 1556 & 2200 & 2028 & 2709 & 2804 \\
\hline
\end{tabular}

Source: Oficina Española de Patentes y Marcas 
Table 4: Estimation results of the knowledge production function

\begin{tabular}{|lrr|lrr|}
\hline \multicolumn{1}{|c|}{ Variables } & Estimate & \multicolumn{1}{c|}{ s.e. } & \multicolumn{1}{c|}{ Variables } & Estimate & \multicolumn{1}{c|}{ S.e. } \\
\hline R\&D & 0.196 & $0.078^{* * *}$ & R\&D & 0.187 & $0.082^{* * *}$ \\
KH & 0.848 & $0.45^{* *}$ & KH & 1.416 & $0.33^{* * *}$ \\
R\&D-Total & -0.059 & 0.168 & R\&D-N & 2.65 & $0.848^{* * *}$ \\
KH-Total & -15.96 & 10.214 & KH-N & 0.976 & 0.658 \\
Population & -0.34 & 0.628 & Population & -0.435 & 0.73 \\
& & & & & \\
No. Obs. & 270 & & No. Obs. & 270 & \\
Log-likelihood & -1117.17 & & Log-likelihood & -1110.2 & \\
& & & & & \\
Delta & 0.61 & $0.094^{* * *}$ & Delta & 0.537 & $0.069^{* * *}$ \\
\hline
\end{tabular}

\begin{tabular}{|c|c|c|c|c|c|}
\hline Variables & Estimate & s.e. & Variables & Estimate & s.e. \\
\hline R\&D & 0.171 & 0.038 & R\&D & 0.276 & 0.085 \\
\hline KH & 2.111 & $0.129^{\star * \star}$ & KH & 1.221 & $0.441^{* *}$ \\
\hline R\&D-KM & 2.456 & $0.123^{\star \star \star}$ & R\&D-TF & 0.871 & $0.312^{* * *}$ \\
\hline KH-KM & -1.108 & -0.798 & KH-KM & -3.462 & 2.459 \\
\hline Population & -0.407 & -0.796 & Population & -1.299 & 0.998 \\
\hline No. Obs. & 270 & & No. Obs. & 270 & \\
\hline Log-likelihood & -1112.6 & & Log-likelihood & -1114.3 & \\
\hline Delta & 0.722 & $0.115^{\star \star \star}$ & Delta & 0.56 & $0.091^{* * *}$ \\
\hline
\end{tabular}

Note: Results correspond to the Negative Binomial model as it is based on less restricted assumptions about the variance of observations than the Possion model. All regressions have been estimated introducing fixed effects and time dummies.

The endogenous variable is the number of patents. The asterisks, ${ }^{*},{ }^{* *}$, and ${ }^{* * *}$ indicate significance at the $10 \%, 5 \%$, and $1 \%$ level, respectively.

The dataset includes 270 observations (15 regions over the period 1986-2003). 
Figure 1. The distribution of patents in the Spanish regions

1986

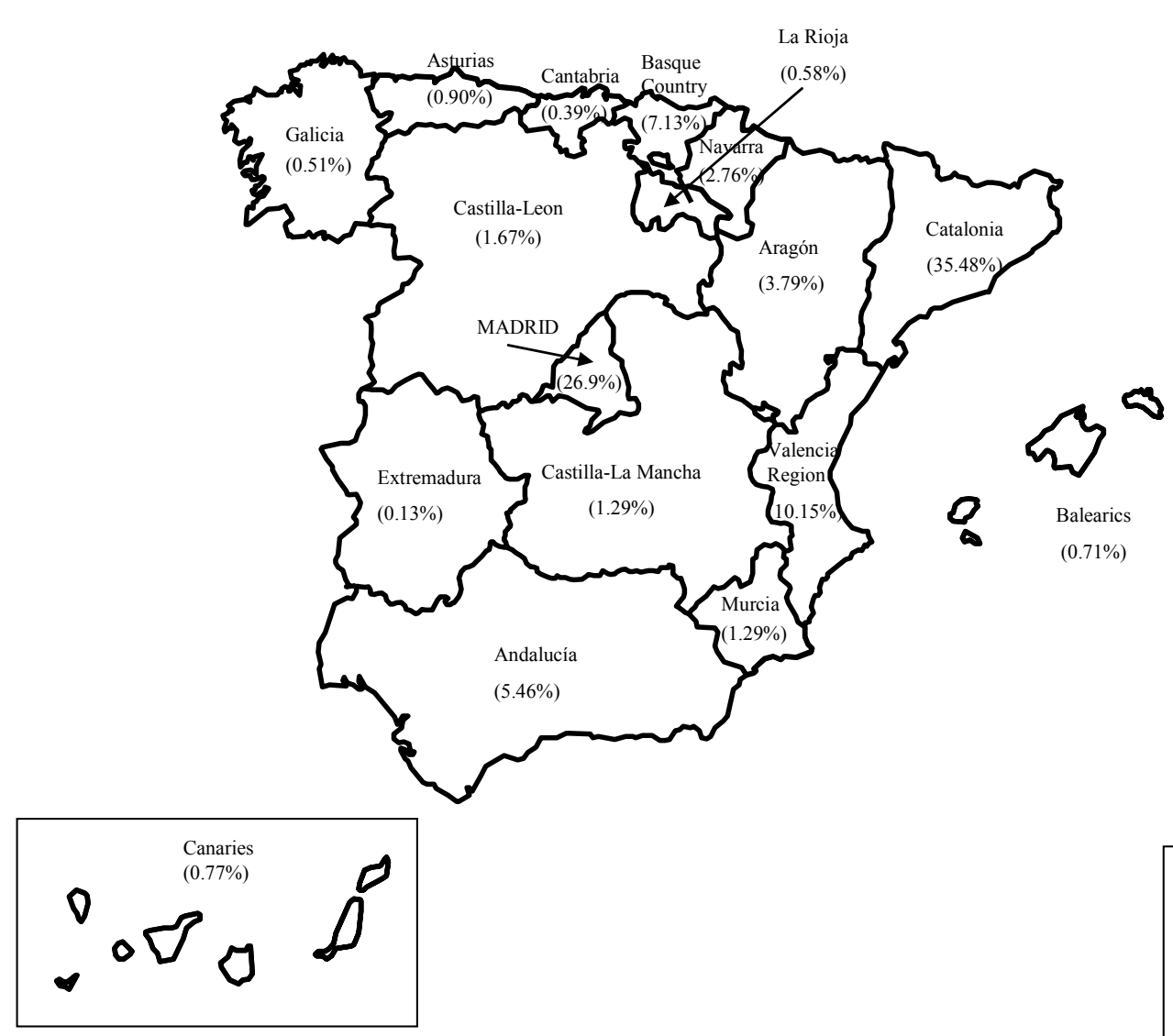

2003

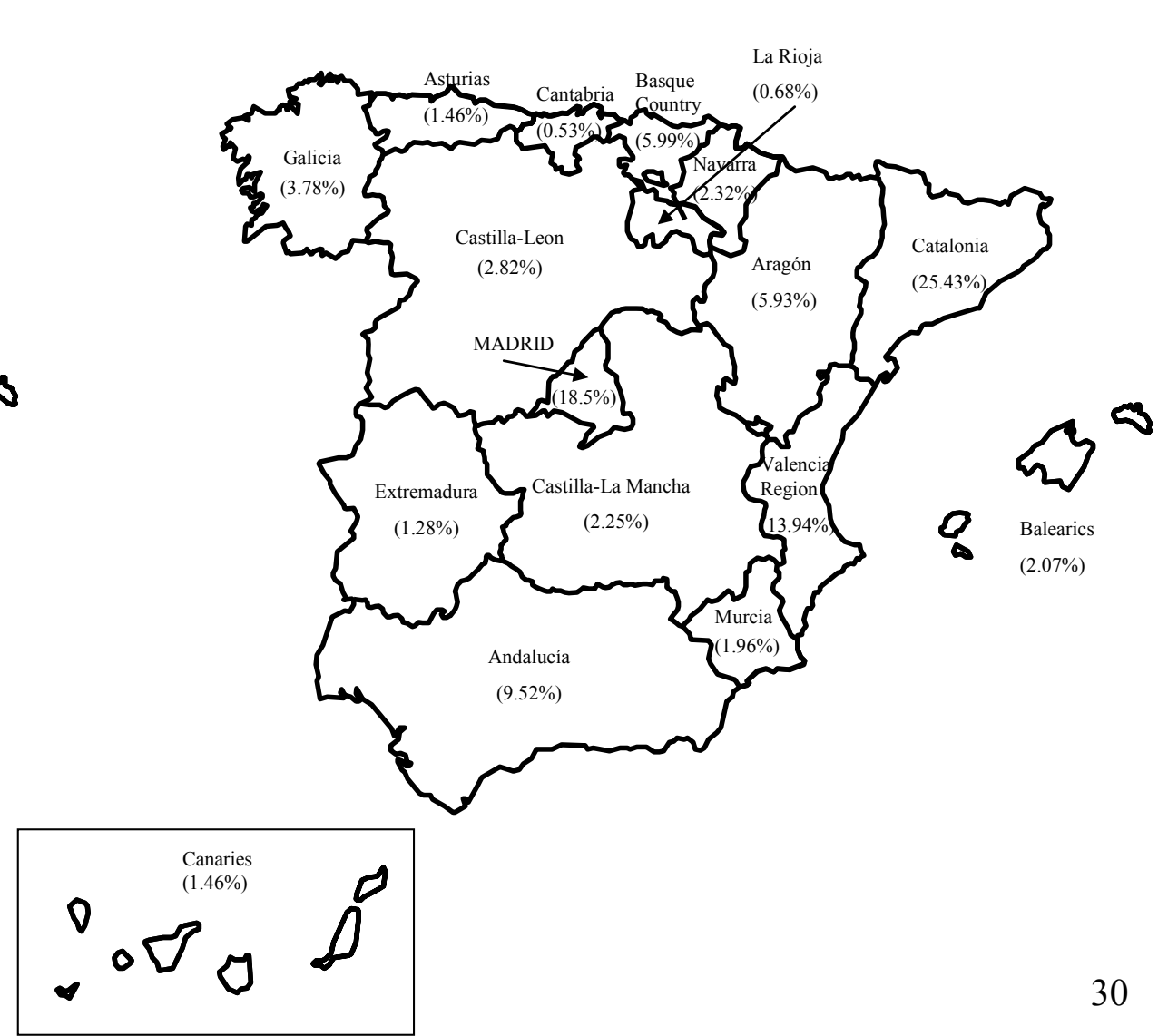

